\title{
Program for Fair Recovery: 1 Job Security in the Forestry Industry
}

In 1981, the wood-using industries employed 372000 Canadians. Between 1981 and 1982, 66000 jobs were lost (see Table 1). During the last year, the industry's levels of production and corporate profits have begun to recover. Sales increased, unit costs fell and after-tax profits rose. This recovery is expected to continue throughout 1984. The improvement in the corporate sector has not been reflected in employment. Between 1982 and 1983 , only $14 \%$ of the jobs lost during the recession were regained, and neither industry or governments are taking advantage of the recovery to make the investments necessary to improve the future job potential of the industry. The International Woodworkers of America (IWA) estimates a permanent loss of 4500 jobs due to plant closures, down-sizing and modernization.

\begin{tabular}{lccccc}
\hline \multicolumn{6}{c}{ Table 1. Employment in the forest industries (thousands). } \\
\hline & forestry & paper & $\begin{array}{c}\text { allied } \\
\text { wood }\end{array}$ & total & $\begin{array}{c}\text { \% unem- } \\
\text { ployment }\end{array}$ \\
\hline $\mathbf{1 9 7 9}$ & 77 & 141 & 140 & 358 & 16.1 \\
$\mathbf{1 9 8 0}$ & 71 & 143 & 135 & 349 & 17.9 \\
$\mathbf{1 9 8 1}$ & 78 & 145 & 139 & 372 & 19.9 \\
$\mathbf{1 9 8 2}$ & 63 & 136 & 107 & 306 & 28.7 \\
$\mathbf{1 9 8 3}$ & 75 & 125 & 115 & 315 & 25.3 \\
\hline
\end{tabular}

Source: Statistics Canada

The forest industries have traditionally been very vulnerable to changes in international demand. Although international demand factors will continue to affect production in the sector, there are ways of both lessening their impact and strengthening the job prospects.

Numerous studies have stressed the need for greater input into forest renewal. Estimates of the backlog of understocked forest land run as high as 25 million ha and this is being added to every year. Industry has played a very small role in reforestation. Similarly Canada lags seriously behind its chief competitors in $R$ \& $D$ related to forestry. Here, too, the record of Canadian industry is poor. Increased reforestation and plant modernization could double the demand for foresters and triple that for technicians in the next few years.

Currently Canada exports most of its forest products to the United States, Western Europe and Japan. This concentration of our foreign markets not only makes the sector very vulnerable to economic conditions in those countries, but also restricts expansion of processed timber products. We continue to lose potential jobs by exporting our timber in raw form rather than processing it here, and part of the problem has been the unwillingness of the existing industry to develop new markets for processed timber products.

\section{The NDP Alternative}

The federal government could take the initiatives outlined below both to expand the job potential of the forestry sector and to minimize the effect of fluctuations in export demand.

\footnotetext{
1The federal New Democratic Party policy statement on forestry. February 6.
} 1984.

\section{Increase publlc Investment In forest renewal.}

Federal spending on forest renewal should be doubled to $\$ 220$ million annually for the next five years. Last year, the Liberals announced that they would spend $\$ 150$ million in forest renewal. Their performance fell far short of this target and their commitments for 1984 are less than the total proposed for 1983

\section{Encourage greater skill tralning.}

An effective skill-training program would:

(a) provide information on new job openings and evaluate skill-training needs; and

(b) assess a pro-rated levy on firms in the industry to fund training. Firms conducting approved programs would receive grants to cover the cost of training. Firms training large numbers of workers would receive grants exceeding their levy; while those not training would still pay their levy to discourage pirating of skilled workers.

A committee made up of business, labour and government representatives would be established to run the program.

\section{Restore $R$ \& D funding to levels in competitive countries.}

Canada's effort in R \& D funding must be at least doubled to reach levels in competing countries. A greater proportion of this funding, however, must go to new products research.

\section{Better coordinated and expanded marketing efforts.}

Greater efforts must be made to expand markets into North Africa, the Middle East and China. This would involve more stable funding for the Cooperative Overseas Market Development Program.

\section{Tie corporate tax Incentives to performance levels in forest renewal, $R$ \& D, resource processing and/or job growth.}

Our tax dollars should be used to supplement public investment in forest renewal, $R$ \& $D$, resource processing and job growth rather than promoting company mergers and introduction of labour-saving technologies.

\section{Create a federal ministry of forestry.}

The ministry would coordinate and improve federal programs and expenditures in R \& D and skill-training, and provide a more effective framework for marketing forest products.

\section{Create a Single-Industry Town Diversification Fund.}

Joint federal/provincial action should be taken to establish community-based advisory boards to look into diversification possibilities for single-industry towns. These boards would consist of industry, labour and other federal and provincial governments. Government funding should be available to help finance private or cooperative investments in viable diversification investments. In addition, federal labour codes should be amended to provide greater employee consultation and job protection in the introduction of technological change. 


\section{The Last Stand 1}

\section{Summary of Recommendations}

There is no reason why the firms that produce pulp and paper should manage the public forests of Ontario. No further forest management agreements should be signed until alternative forms of forest administration are fully investigated. One such administrative structure already in existence is the Algonquin Forestry Authority. The principal task for these new, independent forest authorities would be to harvest and market wood from the lands under their control and manage these lands on a sustained yield basis.

An independent commission of Inquiry should be established to look into the state of Ontario's forests. The commission would develop a realistic assessment of the wood supply situation.

The commission would make specific recommendations to increase the effectiveness of renewal efforts. The commission should consider such proposals as:

- a complete re-evaluation of Ontario's forest resource inventory. (At present the government has only the most vague idea of what is actually growing in the forest.)

- a complete overhaul of current forest management planning systems.

- the establishment of a forest renewal fund into which a set proportion of forest revenues would be paid as a guaranteed soruce of financing for reforestation.

- getting more foresters and forest technicians into the field so that they can actually get down to the job of managing the forest.

The Crown Timber Act should be amended to make sustained yield forestry a statutory requirement in Ontario. An independent forester should be hired to scrutinize both public and private reforestation efforts. This auditor general for forestry would report regularly on the health of the resource.

The Ministry of Natural Resources should make available to the public the industry-government report on wood utilization that it received over a year ago. The government must formulate and implement a comprehensive wood utilization policy based on consultation with labour and community-based groups as well as industry.

A Northern Forest Research Centre should be established in Northern Ontario to investigate ways of improving reforestation efforts in the specific conditions in the north.

The government must immediately develop a forest production policy. This basic document should set realistic production targets and spell out in detail how they will be achieved.

There is an urgent need for more foresters to be employed doing the vital job of renewing the province's forests. More of these foresters should be engaged in field work so as to develop a body of expertise in this area.

'Report of the Ontario NDP Task Force on Forestry.

\section{Some Questions for Your Federal Candidate Ideas for the Political Forester}

One can confidently say that there is a federal election on the way! It is an opportunity for all foresters to make the profession more visible and to get some forestry issues injected into the debate. Here are just a few ideas for questions you might consider posing to your local political candidates. Remember: Standup, Speak up, Speak clearly, and K.I.S.S. (Keep it simple stupid). The philosophy behind the questions is not to corner the candidates but to give them an opportunity to expound on forestry if they can, and perhaps make them realize they should bone up on the subject if they find themselves unable to respond.

1. The Constitution gives the province direct jurisdiction over forestry matters. What is your position on the federal government's role in managing, protecting and using the nation's forests? Should it do more? less? anything?

2. Canadian investment in all aspects of forest management from all sources is about $\$ 1$ billion a year. The CIF/IFC says it needs to be doubled over the next ten years. Where do you and your party stand on increasing the investment in forest management?

3. The forestry profession states that it must use chemical insecticides and herbicides to protect growing forests from insect attacks and competition from unwanted vegetation. Have you developed a position or viewpoint on this question?

4. Canada spends about $1 \%$ of Gross National Product on all aspects of research whereas Sweden spends 2.5\% and is increasing this by $2 \%$ annually in real terms. Would you take steps to increase Canadian research programs and what would some of these steps be?

5. Some very good forestry is practiced on private land holdings both in Canada and the United States. With the current trend toward "privatizing" government functions and the "downsizing" of government generally, do you think that selling forest lands to private corporations is a viable alternative?

6. The forestry sector of the economy has periodically suffered serious management-labor disruptions. Have you any prescriptions for reducing these interruptions in the productive economic life of the country?

7. Do you agree that the job of reforesting an area that has been harvested for forest products should be considered as part of that forest harvesting operation? Who should be responsible for establishing the next crop?

8. Forest based companies have repeatedly over the years claimed that lack of secure tenure over the forest discourages them from investing in forest management. What answer would you give to this?

9. Michael Valpy of the Globe \& Mail in discussing the need to support the Canadian Aircraft Industry says that if we don't, we risk "imprisoning ourselves in the economically suicidal role of hewers of wood and drawers of water" (Globe \& Mail Sept 8/83). Would you comment on this please in light of the fact that 1 job in 10 in Canada is dependent on the forest-based sector?

10. In your vision of our country's future do you think the renewable resource industries will continue to play a strong role or shall we, as some pundits suggest, find our future in high technology?

These are as I say, simply some ideas and Institute members will, I am sure, be formulating much better questions that pertain to their own locale. Some good source documents are: The CIF/IFC brief to the Macdonald Royal Commission as published in the February ' 84 Forestry Chronicle. See also the articles on forest policy in B.C., Ontario, Quebec and New Brunswick as they appear in the April ' 84 Forestry Chronicle. Good Luck.

R.J. Bourchier Executive Director 


\section{Meeting Between CFPFA with the Hon. Charles Caccia}

Representatives of the Canadian Federation of Professional Foresters' Associations met with Mr. Caccia on September 12 1984. The original purpose of the meeting was to discuss the federation's position paper on herbicides, which had been submitted to four federal ministers in September 1983. It was agreed, however to broaden the agenda to include: (1) herbicides and pesticides, (2) National Forestry Week, (3) CFPFA brief to the Macdonald Commission, (4) land for timber production, (5) harvesting and forest renewal, (6) private land forestry, and (7) acid rain.

Dr. Gilbert Paillé President of CIF/IFC acted as leader of the group that included:

D.D. Lockhart - Representing Association of Registered Foresters of New Brunswick

C. Turmel - Representing Ordre d'ingénieurs Forestier du Québec

J.D. Coats - President of Ontario Professional Foresters Association

R.J. Bourchier - Executive Director of Canadian Institute of Forestry/Institut Forestier du Canada

Allen Hopwood - Representing Association of British Columbia Professional Foresters.

Mr. Caccia was accompanied by Mr. Richard Herring, Acting ADM of the CFS, Dr. Carl Winget and four members of the Ministers immediate staff.

Brief notes on the discussions follow:

1. Herbicides and Pesticides: Bourchier reviewed the salient recommendations of the position paper emphasizing recommendations $3,5,6,9$ and 10 or the need for a more co-ordinated federal approach to registration, research requirements and the necessity of a better informed public. In the discussion, these points were again emphasized and Mr. Coats pointed out the need for leadership in dispelling serious misconceptions that surround the use of herbicides and pesticides. Mr. Caccia suggested that a Commission or Parliamentary Inquiry might be a useful exercise to stimulate national debate and perhaps clarify some of the issues. I expect we shall hear more on this idea.

2. National Forestry Week: The CFPFA group expressed strong approval of the department's support of Forestry Week in 1984. A Ministerial Proclamation was suggested and agreed to.

3. Macdonald Royal Commission: Dr. Paillé outlined the main recommendations of the CFPFA brief. The Minister noted that he had had discussions with Mr. Macdonald and felt that forestry had a strong ally. Mr. Caccia urged the Federation to be involved in round II of the Commission's inquiry. In response to a question, he outlined the status of the negotiations on federal-provincial forestry agreements. $\mathrm{He}$ considered that the previously announced dollar-figure would not likely be attained ( $\$ 130$ million), but that some important lessons had been learned, i.e. (1) the timing should be staggered so that not all agreements (or almost all) come up for renewal in one year, (2) the federal and provincial roles must be better defined.

On the question of how can we help get commitment from the government, the Minister stated that Associations like ours should consult with the Minister of Finance when he calls for pre-budget consultations.

4. Land Available for Timber Production: Mr. Lockhart opened the discussion by noting that the removal of land from timber production was a serious problem in parts of Canada and explained that CFPFA, as its $1984-85$ project, was attempting to get a quantitative estimate of the pace and location of the a lienation of forest land. It was emphasized that our efforts were to complement the more detailed and longer term project by CFS.

5. Harvesting and Forest Renewal: Messrs Paillé and Turmel stressed the close relationship that exists between harvesting methodology and subsequent forest regeneration. There is much more to forest renewal that straight tree planting, attractive as this is politically. Improved harvesting with an eye toward the next crop, adequate protection and access were all identified as part of more intensive forest management. The Minister seemed receptive.

6. Private Land Forestry: Mr. Coates opened discussion, noting importance of these lands and the current reviews underway in several provinces. The matter of income tax treatment was discussed and $\mathrm{Mr}$. Caccia reported that CFS had made some proposals on this to $\mathrm{Mr}$. Lalonde before the last budget. These proposals were not taken up and $\mathrm{Mr}$. Caccia suggested that we discuss the question further with CFS.

7. Acid Rain: Bourchier praised the Minister's activities in seeking solutions to the problem but urged some caution in claiming present serious damage to the forest estate. He stated that there was sufficient reason in the damage to lakes and buildings to justify an acid rain clean-up. $\mathrm{Mr}$. Caccia described what forest damage he had seen recently in Europe and feels that is a major concern.

In closing the discussions, which lasted more than $1 \frac{1}{2}$ hours, Mr. Caccia drew attention to the proposed Ottawa office for the Association of University Forestry Schools of Canada. He suggested there was an opportunity for the professional forester's associations to co-operate with the forestry schools in providing scientific, technical and professional advice to the federal government.

The CFPFA feels that a good dialogue took place. The Minister was open, friendly and very understanding of the issues raised. His officials said it was the best meeting of its kind so far.

R.J. Bourchier Executive Director

\section{The Institute Helps Install the Governor General}

Our National President, Dr. Gilbert Paillé and Mrs. Paillé, responded to the invitation to represent the Institute at the May 14 ceremonies to install Madame Jeanne Sauvé as Canada's first woman Governor General. Both Madame Sauvé and her husband, Maurice, have forestry connections. She was Federal Minister of the Environment and responsible for the Canadian Forestry Service in the mid 1970's. Maurice Sauvé was Minister of Forestry in the mid 1960's and latterly was a Vice President with Consolidated Bathurst Ltd. in Montreal.

R.J. Bourchier Executive Director 